\title{
Investigation of Factors Hindering Quality Education in Secondary Schools in Mbeya, Tanzania
}

\author{
Dr. Norman Adamson Sigalla King \\ Teofilo Kisanji University, \\ Directorate of Research, Publication, Consultancy and Postgraduate studies \\ P.O. BOX 1014, Mbeya, Tanzania \\ Email: adamsonnorman@gmail.com
}

Doi:10.5296/ijld.v3i6.4843

URL: http://dx.doi.org/10.5296/ijld.v3i6.4843

\begin{abstract}
Quality education is what brings forth manifestable development of any country. We all know that education is a pillar of development of all countries the world over. When we preach education, we normally mean quality education-an education that can provide answers to the problems that we face in our environment. The quest for quality education has become imperative in this modern world. The importance gain legitimacy due to the advancement of technology, which does both, hampering and boosting education, pending to the environmental setting. This article attempts to investigate factors that hinder quality education in Tanzania. It has adopted a qualitative research design, with interview as the main data collection strategy. The study is ethnographic, in the sense that it searches solution to the known problem. Questions have been the modal for stemming the study. Hence, no hypothesis was developed. The researcher has used scholarly group to come up with the findings. Twenty schools were visited and thus twenty scholarly groups consisting of teachers were the responsive sample for the study. The study used purposive sampling method, where only teachers employed with the respective schools formed the scholarly group for interview. Answers were on agreement of the entire group. The study has revealed that there are several factors, which have contributed to the failure of form four students. Those related to inconformity between numbers of teachers versus students, poor quality of textbooks, poor products of pupils joining secondary schools, absence of reliable teachers guide, absence of action based exams, absence of labs, among others. The second set are factors related to the administration of education, which include decision of removing standard four and form two exams, decision to liberate textbooks used in the entire cadre of primary and secondary education among others.
\end{abstract}

Keywords: Quality Education, Poor Performance, Pupils, Development

\section{INTRODUCTION}

Quality education has been the pillar in most parts of the world. The world has been on emphasis of education, which has made it possible for the resolution that requires countries to increase budgets to $6 \%$ by the year (UNDP, 2006). East African countries, for instance have been on increase on education budgets to about $1 \%$, which was offered in some ten years ago (1990-2000), to about 3\% to 6\% (2005-2012). While the budgets are on increase in most countries, the query remains on the quality of education in most of these countries, and especially developing countries such as Tanzania. Quality education refers to skills and knowledge that is potentially able to reflect the level of attainment. It refers to what that level of education can do based on the intent of the same. In this regard, if standard one pupil, according to the designing of the program must know to read and write, then quality of education is the 
ability of the pupils to demonstrate the attainment of reading and writing ability at that very level.

In this view, we contend that each level of education has to back manifestable level of the ability pegged to the students or pupils. Although there are many factors that purport to be supportive for the offering of quality education, yet the thrust of quality education remains on the demonstration of ability of the tenants of that level of education in dealing with problem solving related to the level of education attained. It can be added that even exams intends to gauge that ability as planned in the curricular. Exams are not set to disapprove students, no, but to approve them.

Although many factors are associated with what it takes to have quality education, the most reliable term that expresses the direction to improvement or decline of quality of education is the expression made through exams. The world over, High Distinction (First Class), Distinction (Upper second class), Credit (Lower Second class) and pass provide a fundamental weight of performance of students in the class. Although there are many questions than answers on consistence of these, weigh as expressed in different institution. Norman(2011), posses some serious concerns when indicated that with varied higher education institutions, we are yet to establish a credential which rules out that if a student in one university let us say ' $\mathrm{A}$ ' attains a distinction, would the same attain distinction in university ' $B$ ' under different lecturers, who are equally markers.

The dilemma posed by Norman, one considered among the guru of education management and problem solving cannot be understated. However, the issue of consistence seem to be decided by the market than certainties of quality, which are subject to willingness of these institutions to harness three main issues. Firstly the understanding of those who teach/lectures, secondly what do we weigh when marking exams and tests and or term papers, thirdly harnessing the grades so that what is considered distinction in one university should the same be recognised in others.

\section{BACKGROUND TO THE PROBLEM}

Tanzania has recently been in demise of education failures if gauged through the performance of form four secondary leavers. The trend of the results from 2009 seems to pose serious challenges for the future development of the country. We appreciate the fact that education is a backbone for development of any country. Hence, the tendencies on the performance of the students tell a lot in relation to future development of the country. For instance, while most students could not access education in 2005 and the previous years, yet from 2006 things changed. The government of the fourth regime decided to work on the numbers through ensuring that most young people go to schools. The drive was important, in that increment of numbers of student was noted, since about 3000 schools were built attracting about ....... Of students in the entire county. The schools built are noted to have been on top record of any regime in Tanzania and has gone beyond the construction of any African country. In addition, the construction of these schools was done within the national budget with half of the funding originating from the people. It was a crucial move to revamp education in Tanzania. For obvious reasons the numbers that increased could be left idle with some small portion positively been used for productive purposes such as agriculture, fishery, and vocational training.

We note that while schools were built, some efforts were made to increase the number of teachers. Some form six students were temporarily recruited to undergo training for six months 
for bridging the gape of teachers in such schools. Irrespective of the perceived concerns by various educational stakeholders, what was made was positive for ensuring a beginning of more numbers in schools.

Equally, the government of Tanzania transformed one of the biggest schools, into educational college for offering degrees instead of Diploma, and forms six certificates. Such conversion was made vivid to Mkwawa High Schools, which was made an affiliate college of the University of Dar es salaam and recruits about 3000 students in teaching profession in total. Chang'ombe teachers college was the second, which recruits about 2000 degree candidates instead of Diploma, which was offered before. These were considered short run measured which intended to increase the number of teachers within a short period.

Further, the government put in place long-term plans for ascertaining enough numbers of teachers in the end. In this vein, the government has to create a university in the capital city Dodoma, which is meant to recruit about 45,000 students of which 16,000 , is school of education. The attempt made by the government provides a prediction to end the teachers' problem in Tanzania by the end of 2014/2015. Currently, the ministry of education recruits about 25,000 teachers from both tertiary and universities.

We are in position to narrate the numbers of teachers not because is the most alarming problem, but from professional point of view, reliability of numbers of teachers versus students is one of the most critical attempt that solves the problems. One can study under the tree; if the teachers are available, things will go on. One can lack textbooks but with the presence of enough numbers of teachers, one can keep on studying and will eventually pass the exam. Some of us went to school and were studying under the trees, yet we passed exams, and could not feel the problems. The presence of teachers necessarily made it possible for the students to pass the exam. Although we are yet to ascertain the perception of people and or teachers, on the magnitude of the problems facing teaching career in Tanzania, yet we can set some propositions based on the professional analysis, which are backed by logical reasoning. Schooling implies students and teachers, then sets of premises such as books and buildings.

The attempt of the government to come up with at least one secondary school in every ward in the year 2006, suggest two emergent challenges: 1) that the product of the named year would not be appealing compared to those taught under normal circumstances. 2) That the products of the subsequent years would again depend on the efforts made after the establishment of the schools, specifically of allocating teachers to the schools. We are ware that numbers of teachers may not connote proper distribution of the same. The guru predicted this; when he narrated that form four students that are about to accomplish their term of 2009 would perform poorly. However, a form four failure is not equal with the none attendant person (Norman, 2007). Hence, the drastic fall in terms of numbers of those who pass exams was predicted. In addition, he notes that most of these students have attained basic education, and have equally grown in maturity by adding about four years of growth, which could not be attained, had there been no such secondary schools. This can be related with the decrease of HIV/AIDS infection as most persuasive age was at school attaining growth, which made it possible to circumstantially avoid the infection of the deadly disease. Not to wonder the national infection rate has decreased from 13\% to about 5\% (NACP, 2012). Much as efforts have been in place to increase numbers of graduates, yet what is persistently been happening poses for the need of research to investigate the causes of the form four leavers failures with the view to assessing the quality of education in Tanzania. In the year 2011, the result of form four students indicate that about 51\% attained a zero class (Ministry of education report, 2012). The report of the 
same ministry this year has again revealed that $63 \%$ of students have attained a zero grade (Ministry of Education, 2013). The questions arise. What is the cause for the failure of form four students in Tanzania? What are the numbers of teachers in schools versus the students required number? What is the quality of books used in the same schools compared to what was used? What are numbers of science teachers versus the number of students? What is the salary of teachers in secondary schools versus other professions in Tanzania? Is salary the cause or mere whim? Is absence of housing the cause for failure or a mere propaganda?

The totality of the questions suggests need for answers that are obtained through critical analysis of the findings obtained through a scientific study.

\section{LITERATURE REVIEW}

Several efforts have been made for the enhancement of secondary education. The efforts have been taken concurrently with those of boosting primary education. At international level, countries have agreed to ensure that primary education is improved through increased resources. As one set of challenges is being solved through the international community's efforts to achieve primary Education for All (EFA) and the Millennium Development Goals (MDGs) throughout the world, another equally large task is unwittingly being created. National governments and donor organizations have concentrated investments on increasing school participation at the primary level in the developing countries (ADEA, 2003).

Education system and the challenges facing it seem to be international in nature. In Pakistan for example, Representatives from Ministry of Education, donors, NGOs, education researchers and teachers highlighted many problems facing school teachers, in particular, low levels of motivation during a National Conference on Teacher Education held in December 2004 organized by Academy for Education Development (AED), USAID and Ministry of Education (MoE). Similarly, a UNESCO report on the 'Status of teachers in Pakistan', published in October 2003, pointed out that non-transparent appointment practices, politicization, poor management, lack of transport and security are amongst the major problems that are faced by teachers. Policy makers and other stakeholders are well aware of the motivation crisis in teaching, but to date have been unable to take effective action to address teacher motivation and incentive needs (Khan, 2005).

The Association for the Development of Education in Africa (ADEA) in the meeting of Mauritius, 2003 noted that most of the poorest countries, including most Sub-Saharan African (SSA) countries are increasing their efforts (resources) to improve access to and quality of primary education. However, in many countries this creates an increasing demand by parents and communities to let their children benefit from the next stages in the education cycle. Access to and successful completion of secondary education shapes the skills mix of the labour force, influencing international competitiveness, foreign investment and prospects for sustained growth (Lewin, 2003a). Several Asian countries, particularly those in East Asia, have successfully coordinated the expansion of education with a rapid transformation of their economies into manufactured goods export, allowing their economies to flourish in the new global economy (African Development Bank, 2003).

Governments must ask themselves what their intended purposes of secondary education and training are. There is an agreed concern that several factors that lead into the improvement of secondary education. However, governments seem to concentrate on the numbers than the strategies to maintain the quality of education (Norman, 2010). In this vein, Bregman (2002) alerted that pressures to expand secondary enrolments would exacerbate the lack of qualified 
secondary education teachers. Additionally, in-service training for teachers is usually insufficient and ad hoc. This causes great wasted potential in the system. In Namibia, for example, despite the new developed systems of education that intends to boost the quality of education through the harmonised instructional system based on progressive approaches such as learner centeredness, multigrade teaching, and differentiated teaching is not fully utilised because of insufficiently prepared teachers (World Bank, 2003).

Therefore, while an attempt is made on looking to various hindrances to education, yet, it is important to develop in-house teachers. In house teachers are vital due to the importance of each cadre of education level. Norman (2005:56) sets some importance of primary education, secondary education, tertiary education and university or higher education. He insists that primary education is meant to educate children to read, write and count in all simple algebraically set mathematics, and that secondary education is meant to equip students with the technical skills, which is capable of making the graduants defeat the challenges of the world, or the environment in which such education is offered. Secondary education is not for teaching the students how to read and write.

Tertiary education is for improving the skills of secondary students and those who have attained such considered equal to secondary school education to add more skills for the furtherance of the former skills and knowledge. We anticipate that this education level will empower students/trainee to accommodate the challenges of unemployment in our countries.

In addition, university education is for specialisation or creation of professional team which is worthy in dealing with matters of analysis, scrutiny, critical thinking for the solvency of societal problem. This could range from health, education, economics, management, architects, law, and so forth. We anticipate that university grandaunts should be few compared to other categories, and is not sin.

From what we have gathered, it can be realised that each category of education has to be well planned including doing away with the hindrances that may deter provision of quality education. The crucial levels of education are primary and secondary education. Hence, cognising factors that hinder good performance of secondary education, is imperative.

\section{DISCUSSION OF THE FINDINGS}

The findings of the study reveal some crucial factors that lead to poor performance of secondary education. The factors are of three major groups, namely those related to the system of education, which is essentially controlled by the ministry of education or any ministry responsible for the provision of the same. The second group of factors are those related to quality of teachers that train primary school students, who are the candidates of secondary education. The third group of factors are those related to resource materials, which the ministry of education mitigate.

a) Removal of form two examinations: It was noted that during the fourth regime, the ministry removed form two exams, which was meant for weighing the ability of students entering form three. The removal of this exam created doom since students could sail up to form four without seating for mandatory exam that intended to gauge the performance of students at that level. Hence, students who were weak could not fear failing the exam, since it was a guarantee that, once a student has joined form one, would equally seat for the screening exam in form four. This affected negatively both, 
the students and the teachers. Teachers' morale to teach students vehemently was reduced since no exam was set for the same. We understand that examinations are benchmarks of both teachers and students. Examinations push students to mandatory study hard so that could pass the exams. On the other hand, exams push teachers to teach intelligently so that students could pass exam and enhance school reputations. Removal of these exams made it hard for students to pass the final exam, hence failure.

b) Poor quality of students joining secondary education: Another factor that was noted to contribute for the failure of students in form four exams is poor quality of students emerging from primary education. It was noted that about 8000 students completed standard seven in Mbeya region could not write and read. It was further noted that some students managed to pass standard seven exams, but could not write and read. Questions are more than answers. How could they pass examinations while they do not know how write and read? The answer is type of the exam, which are multiple choices. Why could they reach standard seven without knowing how to read and write? The two questions suggest for some other factors contributing to the failure of students.

c) Removal of grade four examinations: Findings indicate that removal of grade four exams was the factor leading to the failure of form four students. How? The removal influenced negatively students and teachers spirit to work hard. Pupils could not fear failing since the removal of grade four exam meant that they could sail up to standard seven without any interference. Equally, teachers' morale to work hard was automatically reduced since no measurement for the performance. This act, had for the first time in the history of education in Tanzania, noted standard seven pupils unable to read and write- a very basic requirement of any primary school student. Some of the pupils who were unable to read and write were able to pass standard seven exams. How? This brings another factor for the same.

d) Multiple-choice examinations: The ministry of education has transformed examinations in such a way that examinations are multiple choices. In the past prior to the multiple choices, examinations were not multiple choices. Pupils were supposed to indicate how they have arrived at the answer. Hence, three columns were noted, which are question, work/solution, and answer. This cultivated a sense of not copying since for a student to pass the entire exams, was supposed to show clearly the work done regarding the answer. Invigilators could supervise pupils effectively since the mode of exams supported absence of cheating. Currently exams are multiple choices. As noted in some propositions. If questions are multiple choices, of three ranks, $\mathrm{A}, \mathrm{B}$ and $\mathrm{C}$, the probability for passing the exam is $1 / 3$. Literally, if pupils would do guess work, the possibility for passing such exam is a third of the entire number or close to that. For example if students are 30 , by setting a multiple choices exams, would suggest that about 10 students would pass the exams. It is not right. Examinations are meant to gauge the true performance of pupils or students. Unless supervision is made in a computerised format, result may connote a different story. A more related factor is the spacing between pupils.

e) Space or distance between candidates: The space between pupils seating for the examinations is favourable for pupils to see what one pupil has written on the paper. Normally, two to three metres are favourable for any pupil to see what the neighbour has written. This become favourable when the multiple choices are the mode of the exam, where candidates are supposed to mark A, B or C in a space provided. Looking 
and seeing a letter $\mathrm{A}, \mathrm{B}$ or $\mathrm{C}$ is a simple task for a cheating candidate compared to seeing the entire work for the solution of the question.

f) Change of content based to competence based exams: Findings indicate that the change of content based to competence based was wrongly adopted without critical thinking into reiterating the meaning of the two concepts. Generally, from professional point of view, it is the content, which tells the competence. Hence, the emphasis on one of them may suggest superfluous. The change from content based, which was executed since independence, altered the entire teaching career as teachers college also changed the format from content based to methodology based. This meant that instead of teachers being taught what they will teach, they were trained on the methodology of how to train, without necessarily understanding what to teach. This also is another factor, which can stand-alone. It was further noted that another conflicting conceptualisation was on setting exams, while competence based required gauging the ability of students to understand the concepts (questions) as opposed to content based which by definition it meant being able to answer question asked in the contents provided. Hence, multiple questions were entertained. In other words, in competence based, we do not expect multiple questions.

g) Change of teaching from content to methodology: The ministry of education changed the emphasis from content-based teaching to methodology teaching. The qualities of candidates who join teachers colleges to teach in primary education have varied credentials. In 1990s, for example candidates were those who attained division four, mostly from 30 to 32 points. This means that candidates were those with about two Ds with likely zero pass in the entire set of seven subjects. Generally, the rank in form four students is gauged out of seven subjects. An A to D is awarded point 1 to 4 respectively. In addition, bellow $\mathrm{D}$ is $\mathrm{F}$ not $\mathrm{E}$, which indicate that a student has attained a zero or bellow 21 marks. The credentials have been carrying more weight in recent years where candidates are those with 27 to 29 points. Again, this suggests that candidates are those who have six Ds with one ' $F$ ' or the close related passes. These are generally weak candidates, but can suit to teach at primary school level if and only if are trained on the contents, and methodology. In 2004, the change, which altered the content, based teaching to methodology created a bunch of weak teachers; if at all, the focus was on form leavers. This equally added a number of weak standard leavers, who would later join secondary education through government schools or private schools. The butch can be said candidates of zero division in form four.

h) Market driven education policy on material resources: Currently in Tanzania, we are experiencing a market driven materials resources. This may not necessarily damage the quality of education, much as there is a control of the quality of materials including textbooks. In one school, we found that one topic has been covered in four different books. This was a Civic education textbook. On one topic known as 'types of government', the four books indicate that there are seven, five, four and two types of government respectively. The teacher responsible for the subject asked, 'which one should I use to teach?', 'which book will be used to set an exam'? The four textbooks have been granted a right to be used in secondary schools. Certainly, we lack a proper machinery to examine the quality of material resources. This creates room for form four failures due to poor quality of materials resources, which lack congruence. 
i) Incongruence of teachers versus students' number: It was noted that in the entire schools visited there is lack of congruence between the students and the number of teachers available. This had huge impact on the results of 2009, 2010, 2011 and 2012. It was noted that in 2006, the fourth regime of the government introduced a secondary school per ward. This effort of the government, lead to the establishment of about 3000 secondary school in the country. Nevertheless, there were no corresponding efforts to curb the situation, especially in the year 2006. However, in 2007, the government created room for form six leavers to join teachers college for three to six month for filling the gape of teachers in secondary schools. Indeed, the number was of assistance in reducing the gape. In late 2008, the teachers who attended short course for bridging the gape were required to go to colleges for further studies. The mandatory further training of these teachers necessarily increased the gape of teachers in secondary schools. Hence, in most schools as on the year 2009, there was lack of teachers. Some schools, had only one teacher, and most of them had less than five teachers in the entire school. Hence, the so-called bad result of form four in 2009 up to 2012 were not a shock rather an expected result, if things are observed through an eye of a specialist.

j) Absence of science teachers in secondary schools: It was also noted that, in most schools there were absence of science teachers. For example, in the twenty schools, which were under study, the total number of science teachers, was 24 , which connote an average of 1 to 2 teachers per school. A school with huge number of science teachers had four, with about 1275 students. This school had a shortage of 24 Science teachers. In one school named Isuto, had only one Biology teacher, a subject, which is taught to all streams that are 32 classes. Science teachers feel that they are being infringed since teachers for arts subject may have one session per day while science teachers have about eight sessions. It was noted that lack of science teachers had direct impact in the failure of students in these subjects.

k) Teachers' satisfaction: It was noted that most teachers could mention lack of housing as hindrance to their performance especially to schools located far from village centres. Teachers indicated that they live far from schools and they walk long distances prior to reaching teaching areas. This influenced their poor performance in teaching due to tiresome. However, this was rated among the last credentials, as was a key in schools that are located far from the normal village housing. Such schools in Mbeya District are not many. It should be noted that housing is in need to almost all teachers, however, the extent to which this need influenced failure of students of form four is minimal.

1) Low motivation to Science teachers: Science teachers indicated that there is no motivation for teaching science subjects. The absence of motivation, would suggest absconding in some teaching sessions since their fellow counter parts of arts subjects have single or only two sessions per day.

m) Lack of commitment of parents: teachers indicated that one of the contributing factors to the students' failure on the form four exams was lack of parents commitment on parental care rendered to the children. Parents seem to have lost mandate to their children. For example, an attempt of teachers to punish students, which is legal in Tanzania, will attract parents rebuking teachers. This can be done through verbal expression or through coifing. Some teachers indicated that once a student is punished, parents in the villages to which these parents are affiliated would just retaliate by backbiting. It was again leant that parents have not been able to train their children on 
what it takes to be good students. Modernity has made these students forget the essence of being students.

n) Absence of dormitories for female students: Absence of dormitories was mentioned as one of the leading factor, which lead to poor performance of four students. Most teachers indicated that students are hailing in the villages; hence, they spend much time in collecting for firewood, cooking and other village responsibility. In most of these places, there is no electricity. Hence, villages persuade these female students into practicing early sex. This has been termed credentials that contribute to poor performance of the students in form four examinations.

o) Reduced Moral competence of new teachers: It was noted that most new teachers lack competence in morality, which include acting as parents to children as opposed to peers. Most long serving teachers indicated that new teachers are supposed to be nurtured just as they nurture the students. They look similar in most of the behaviour except on the level of education. The long serving teachers indicated that what differentiates the new teachers and the students is the level of education. In addition, it was leant that differentiating the two is because one teaches and another listens.

p) Weak supervision of daily performance: Another factor contributing to the failure of form four is weak supervision on daily basis pursued through the ward education coordinators. In Tanzania each ward has a mandatory at least one government secondary school, and the entire area is supervised through the Ward Coordinator, who is professionally a teachers. They have not been keen in supervision of these schools. Reckless in supervision has contributed to reckless in teaching.

Table 1: Ranking on factors leading to failure of form four students

\begin{tabular}{|l|l|l|c|}
\hline S/NO & Factor & Frequency & $\%$ \\
\hline 1. & Removal of standard four exam & 20 & 100 \\
\hline 2. & Removal of form two exams & 20 & 100 \\
\hline 3. & Poor quality of students entering form one & 20 & 100 \\
\hline 4. & Incongruence of teachers versus students & 18 & 90 \\
\hline 6. & Incongruence of text books versus students & 20 & 100 \\
\hline 7. & Poor quality of teachers in Primary schools & 14 & 70 \\
\hline 8. & Poor monitoring of educational officers at ward level & 19 & 95 \\
\hline 9. & Poor monitoring of educational officers at district level & 14 & 70 \\
\hline 10. & Poor quality of text books & 20 & 100 \\
\hline 11. & Lack of housing for teachers & 6 & 30 \\
\hline 12. & Poor pay for teachers in secondary schools & 4 & 20 \\
\hline 13. & Absence of Science teachers in secondary schools & 20 & 100 \\
\hline 14. & Absence of dormitories & 20 & 100 \\
\hline 15. & Irresponsiveness of parents on the children & 20 & 100 \\
\hline 16. & Change of content to methodology based teaching & 18 & 90 \\
\hline 17. & Change of contents to competence based exams to students & 12 & 60 \\
\hline 18. & Poor mode of exams -multiple choices & 20 & 100 \\
\hline 19. & Teachers dissatisfaction & 3 & 15 \\
\hline 20. & Reduced moral competence among teachers & 20 & 100 \\
\hline 21. & Weak Supervision by ward education coordinators & 15 & 75 \\
\hline
\end{tabular}


Source: Field data. The findings indicate that there are several factors that influence failure of form four leavers in Tanzania. The leading factors include reduced morality among new teachers, poor mode of exams, irresponsiveness of parents, absence of dormitories, poor quality of text books, absence of science teachers, removal of form four and standard four exams, and poor quality of students joining secondary education.

We have leant several factors that lead into failure of form four students in Tanzania. Researches need to be conducted in primary education to find out what are the factors leading to poor quality of students entering form one. The responses have been on caucus of schoolteachers which did not segregate the new and the long serving. The Tanzania Headmaster Association (TAHOSA) should conduct it important that more researches to find out what is the perception of factors contributing to the failure. Headmasters and Headmistress are long serving teachers, they are important informants regarding factors leading to the failure, and equally can provide solutions for the same.

\section{CONCLUSION}

The factors leading to failure of form four students are several. They range from those, which are due to irresponsiveness of parents, teachers, ministry of education, poor setting of exams, lack of consistence of syllabus, poor quality of textbooks, poor quality of training rendered to teachers in modern colleges in recent years, weak supervision rendered by the educators, and incongruence between exams and policy on exams, among others. The factors suggest more researches on education, which should incorporate primary education, and university education. In primary education, the research should find out factors leading to poor quality of pupils entering form one in secondary school. For example in the year 2012 we had about 319 students who passed standard seven exams in Mbeya region, while they can not read and write. This suggests researches in cognising the quality of both teachers and pupils in primary schools, and equally students joining varsities. We conclude that education is a pillar of development of any country, therefore conceited efforts have to made to ensure that each grandaunt is competent equal to the level has attained.

\section{Acknowledgement}

The Pension Provident Fund (PPF) and the Mbeya Songwe Cement, both in Tanzania, funded this study. Much appreciation for the two organisations. The study has paved way for knowing the factors leading to the failure of form four students from the professional point of view as opposed to mere following the whim. Another study is on progress to investigate the role of educational administration in boosting or hindering the improvement of performance in secondary and primary education.

\section{REFERENCES}

Bregman, Jacob, Marit Granheim, Steffi Stallmeister (2003). "Secondary education reform trends in OECD countries and possible best practices for Sub-Saharan African Countries"; SEIA, AFTHD, World Bank, in preparation.

Bregman, Jacob and Steffi Stallmeister(2002). "Secondary education In Africa: strategies for renewal”; Africa Region, AFTHD, World Bank, June 2002.

Bregman, Jacob and Pai Obanya (2003). "Secondary Education in Nigeria: Contemporary challenges and future demands"; Part of SEIA outputs, AFTHD, World Bank, Washington, D.C. 


\section{Macrothink $\Lambda$ Institutem}

Bregman, Jacob, George Bethel and Karen Bryner (2002). "Rwanda Secondary Education Strategy paper", paper prepared with contributions from the Rwanda Ministry of Education and Sports; based on a mission to Rwanda in July-August 2002. AFTH3, World Bank, Washington, DC.

Bregman Jacob and Bryner Karen (2003). Quality of secondary education in Africa, Association for the Development of Education in Africa ADEA Biennial Meeting 2003 (Grand Baie, Mauritius, December 3-6, 2003)

Khan T. (2005). Teacher Job satisfaction and incentives: A case study of Pakistan.

Lewin, Keith M (2003a). Investigating the Missing Link-The case for expanded secondary schooling in Sub-Saharan Africa.

Market Data Retrieval. (2003). MDR - Successful school marketing starts here (2002-2003).Shelton, CT: Market Data Retrieval, A Company of D\&B.

Martinez, D. (2001). Predicting Student Outcomes Using Discriminant Function Analysis. Paper presented at the Annual Meeting of the Research and Planning Group, Lake Arrowhead, CA.

Mason, W.S. (1961). The beginning teacher: Status and career orientations (Circular No. 644). Washington, DC: Government Printing Office.

National Education Association. (2004). Attracting and keeping quality teachers. Retrieved March 21, 2013, from www.nea.org/teachershortage.html The Elementary School Journal, 89, 421-439

Norman, A.S (2005). Development is a war what do we do? Lefkosia, Cyprus.

Norman, A.S (2010). Maximizing students potentials in higher learning institutions: some hints and tips, Educational Research (ISSN: 2141-5161) Vol. 1(11) pp. 556-560 Available online http://www.interesjournals.org/ER retrieved on 21 January, 2013.

Rabinowitz, W., \& Crawford, K. E. (1960). A study of teachers' careers. The School Review, 68 (4), 377-99.

Rickman, B. D., \& Parker, C. D. (1990). Alternative ways and teacher mobility: A human capital approach. Education Review, 9, 73-79.

Riehl, C., \& Sipple, J. W. (1996). Making the most of time and talent: Secondary school organizational climates, teaching task environments, and teacher commitment.

American Educational Research Journal, 33 (4), 873-901.

Rosenholtz, S. J. (1989). Workplace conditions that affect teacher quality and commitment.

UNAIDS (2000). HIV/AIDS and the Education Sector. Programme Coordinating Board. 11 April 2000, Geneva.

Watkins, Kevin (2000). The Oxfam Education Report. Bath, UK: Redwood Books. 
World Bank. (2001). A Chance to Learn: Knowledge and Finance for Education in Sub-Saharan Africa. Sector Assistance Strategy, Africa Region Human Development Series, Washington, D.C.

World Bank (2002). Skills Development in Sub-Saharan Africa. Washington, D.C. 